\title{
Relationship between metabolic profile, diseases, productive and reproductive performance in high- producing Holstein cows in the postpartum period
}

\author{
Relação entre o perfil metabólico, doenças, \\ desempenho produtivo e reprodutivo de vacas \\ Holandesas recém-paridas de alta produção
}

Eloize Jaqueline Askel ${ }^{1}$; Tiago Andre Frigotto2; Rodrigo Barros Navarro3; Ivan Roque de Barros Filho4; Rudiger Daniel Ollhoff5; Rodrigo de Almeida6*

\section{Highlights}

Approximately half of periparturient cows had clinical diseases in the postpartum.

Sick cows showed higher serum beta-hydroxybutyrate concentrations at 5 days in milk.

Postpartum diseases have a detrimental impact in the productive performance of cows.

\section{Abstract}

The present study aimed to monitor Holstein cows in the postpartum period, and to evaluate the occurrence of clinical diseases and their relationship with metabolic profile, milk yield and composition, and reproductive performance. One hundred and five Holstein cows, 32 primiparous and 73 multiparous, from two dairy herds in Arapoti, Paraná State, were clinically monitored up to ten days after calving. The clinical occurrences diagnosed were: dystocia, metritis, retained placenta, clinical hypocalcemia, displaced abomasum, mastitis, pneumonia, and digital dermatitis. Blood samples were collected at one, two, five, and ten days postpartum for analysis of non-esterified fatty acids (NEFA), $\beta$-hydroxybutyrate (BHB), and total calcium. Individual milk yield was measured up to 100 days in milk (DIM), and the first test-day was evaluated for milk composition. Statistical analyses were conducted using the MIXED procedure of SAS, and the fixed effects of farm ( $A$ and B), parity (primiparous and multiparous), and occurrence of clinical diseases (sick and

1 Veterinary, M.Sc. in Animal Science, Universidade Federal do Paraná, UFPR, Curitiba, PR, Brazil. E-mail: elojaque@ gmail.com

2 Prof. Dr., Departament of Veterinary Medicine, Pontifícia Universidade Católica do Paraná, PUCPR, Toledo, PR, Brazil. E-mail: tiago.frigotto@pucpr.br

3 Veterinary, M.Sc. in Animal Science, Capal Cooperativa Agroindustrial, CAPAL, Arapoti, PR, Brazil. E-mail: rodrigo@ capal.coop.br

${ }^{4}$ Prof. Dr., Departament of Veterinary Medicine, UFPR, Curitiba, PR, Brazil. E-mail: ivanbarf@ufpr.br

${ }^{5}$ Prof. Dr., Graduate Program in Animal Science, School of Life Sciences, Pontifícia Universidade Católica do Paraná, PUCPR, Curitiba, PR, Brazil. E-mail: daniel.ollhoff@pucpr.br

6 Prof. Dr., Departament of Animal Science, UFPR, Curitiba, PR, Brazil. E-mail: ralmeida@ufpr.br

* Author for correspondence

Received: Mar. 15, 2021 - Approved: June 07, 2021 
healthy cows) were included. Forty-eight cows (45.7\%) had one or more clinical occurrences. In these sick cows, the BHB concentration at five DIM was higher $(P=0.06)$ than in healthy cows; 0.78 and $0.57 \mathrm{mmol}$ $L^{-1}$, respectively. Regarding milk yield, cows with one or more clinical occurrences had lower $(P<0.01)$ daily milk yield up to 30 DIM, and had a tendency of lower $(P=0.09)$ accumulated production up to 100 DIM than healthy cows. Sick cows had a tendency to show lower $(P=0.08)$ milk total solids content than healthy cows; 12.04 and $12.60 \%$, respectively. There were no significant differences between sick and healthy animals in the remaining milk components, or the reproductive parameters assessed. The differences observed for days in the first artificial insemination (AI), Al number, and days open occurred due to the effect of the herd. Key words: Clinical disorders. Milk yield. Transition period.

\section{Resumo}

O objetivo deste estudo foi monitorar vacas Holandesas no pós-parto e avaliar a ocorrência de doenças clínicas e sua relação com o perfil metabólico, a produção de leite e sua composição e o desempenho reprodutivo. Foram monitoradas clinicamente durante 10 dias após o parto, 105 vacas da raça Holandesa, 32 primíparas e 73 multíparas, de dois rebanhos leiteiros em Arapoti, Paraná. As ocorrências clínicas diagnosticadas foram: distocia, metrite, retenção de placenta, hipocalcemia clínica, deslocamento de abomaso, mastite, pneumonia e dermatite digital. Amostras de sangue foram coletadas nos dias 1, 2, 5 e 10 após o parto para análises de ácidos graxos não-esterificados (AGNE), $\beta$-hidroxibutirato (BHB) e cálcio total. A produção de leite individual foi mensurada até 100 dias em leite (DEL) e para a composição do leite foi avaliado o primeiro controle leiteiro oficial após o parto. As análises estatísticas foram conduzidas pelo procedimento MIXED do SAS e foram incluídos os efeitos fixos de fazenda (A e B), paridade (primíparas e multíparas) e ocorrência de doenças clínicas (vacas doentes e saudáveis). Quarenta e oito vacas (45,7\%) apresentaram uma ou mais doenças clínicas. Nestas vacas doentes a concentração de BHB no 50 dia pós-parto foi superior $(P=0,06)$ a de vacas saudáveis; 0,78 e $0,57 \mathrm{mmol} \mathrm{L}^{-1}$, respectivamente. Em relação a produtividade, vacas com uma ou mais doenças clínicas apresentaram menores $(P<0,01)$ produções diárias até 30 DEL e tendência de menores $(P=0,09)$ produções acumuladas até 100 DEL em relação a vacas sadias. Vacas doentes apresentaram uma tendência de menor $(P=0,08)$ porcentagem de sólidos totais no leite do que vacas saudáveis; 12,04 e 12,60\%, respectivamente. Não houve diferenças significativas entre animais doentes e saudáveis para os outros componentes do leite, bem como nos parâmetros reprodutivos avaliados. As diferenças observadas para dias até a primeira inseminação artificial (IA), número de IA e dias abertos ocorreram devido ao efeito de rebanho.

Palavras-chave: Doenças clínicas. Período de transição. Produção de leite.

\section{Introduction}

The transition period is the phase between three weeks before and three weeks after parturition of dairy cows. During this period, metabolic changes and a decreased immune response occur, which predispose to metabolic and infectious diseases in periparturient cows (Sordillo \& Raphael, 2013). These disorders decrease productive performance (Carvalho et al., 2019; Dubuc, Duffield, Leslie, Walton, \& Leblanc, 2011; Wittrock, Proudfoot, Weary, \& Von Keyserlingk, 2011), compromise reproduction (Carvalho et 
al., 2019; Dubuc et al., 2011; Giuliodori et al., 2013), and increase culling rate (Carvalho et al., 2019; Wittrock et al., 2011).

The most prevalent diseases that affect dairy cows typically occur at the beginning of lactation, within 60 days in milk (DIM), so this period is the most critical (Carvalho et al., 2019). The economic impact occurs due to costs associated with treatments and productive losses, as well as the involuntary culling of cows (Overton \& Waldron, 2004).

Metabolic or infectious disorders that affect periparturient cows such as retained placenta, puerperal metritis, hypocalcemia, ketosis, displaced abomasum, and others typically have a metabolic element as a causal or associated component. Cows with non-esterified fatty acids (NEFA) and $\beta$-hydroxybutyrate (BHB) levels above critical thresholds showed a greater incidence of ketosis and displaced abomasum (Ospina, Nydam, Stokol, \& Overton, 2010a) and reduced reproductive performance (Ospina et al., 2010b). In cows with metritis, a higher concentration of BHB was also observed immediately after calving compared to healthy cows, and factors such as dystocia, retained placenta, and stillbirths increased the metritis risk (Giuliodori et al., 2013). In addition, clinical disorders reduced milk yield and appear to have long-term effects on dairy cow physiology, which compromise performance even after clinical recovery from the health problem, and contribute to the costs of the occurrence of clinical diseases (Ribeiro et al. 2016).
Thus, the current study aimed to monitor the clinical status of periparturient cows, categorizing them as healthy or sick, and their relationship with serum metabolites. In addition, it aimed to verify the effect of clinical disorders on productive and reproductive parameters during the postpartum period.

\section{Material and Methods}

Two commercial dairy herds in Arapoti, Paraná State, Southern Brazil (located at $24^{\circ}$ 8' 43" S and 49 49' 8" W, and $841 \mathrm{~m}$ altitude) were monitored for four months (April to July). Both herds had their lactating cows in a freestall system, with three milkings a day, and an average milk production per cow during lactation of $10.675 \mathrm{~kg}$. One hundred and five Holstein cows were evaluated; 26 (24.8\%) from herd $A$ and 79 (75.2\%) from herd $B$, and 32 primiparous $(30.5 \%)$ and 73 multiparous (69.5\%). Both herds provided acidogenic diets in the prepartum period, with urinary $\mathrm{pH}$ monitoring. The postpartum total mixed rations were balanced according to the nutritional requirements for cows at the beginning of lactation and are shown in Table 1, which also includes the chemical composition of the diets. 
Table 1

Ingredients and nutrient composition of cow's postpartum diets in herds A and B

\begin{tabular}{lcc}
\multicolumn{1}{c}{ Item } & Herd A & Herd B \\
\hline Ingredient, \% of DM1 & & 37.5 \\
Corn silage & 41.5 & 6.4 \\
Wheat silage & - & - \\
Grass hay & 6.4 & 28.4 \\
Commercial concentrate & 13.5 & - \\
\hline High moisture corn & 15.2 & 8.8 \\
Cottonseed & 11.8 & 5.0 \\
Soybean meal & 7.7 & 5.9 \\
\hline Wet brewers grains & - & 5.0 \\
Citrus pulp & - & 1.20 \\
Rumen-protected fat & 0.95 & 0.55 \\
\hline Protected urea & 0.65 & 0.85 \\
Sodium bicarbonate & 1.00 & 0.40 \\
Mineral-vitamin mix & 0.65 & - \\
\hline Limestone & 0.65 & \\
Nutrient composition, \% of DM & & 46.3 \\
\hline DM, \% & 45.7 & 73.8 \\
\hline Total digestible nutrients & 72.5 & 17.2 \\
Crude protein & 16.3 & 32.5 \\
\hline Neutral detergent fiber & 36.6 & 19.5 \\
\hline Acid detergent fiber & 21.1 & 6.1 \\
\hline Fat & 5.9 & 0.82 \\
\hline Calcium & 0.78 & 0.42 \\
\hline Phosphorus & 0.40 & \\
\hline
\end{tabular}

1 Dry matter.

All cows were evaluated daily by clinical examination for the first ten days after calving to detect possible diseases. The cows were evaluated after milking, restraining them in individual chutes to aid physical examination. Retained placenta was defined as the presence of fetal membranes for 24 hours after calving (Dubuc et al., 2011); displaced abomasum when there was a metallic sound on auscultation and percussion of the left abdomen (Ospina et al., 2010a); mastitis when there was a change in the physical aspects of the milk (presence of lumps) (Carvalho et al., 2019); clinical hypocalcemia when there was a prolonged decubitus of 48 hours after calving, with no success in standing up (Venjakob, Borchardt, \& Heuwieser, 2017); pneumonia when there was fever, difficulty breathing, and crackling on respiratory auscultation (Carvalho et al., 2019); metritis was characterized by 
fever and a foul-fetid vulvar discharge (Ospina et al., 2010a); and dystocia when there was difficulty in the progression of calving, with human intervention to the end (De Amicis, Veronesi, Robbe, Gloria, \& Carluccio, 2018).

Blood samples were collected after morning milking, before the first daily meal, at one, two, five, and ten DIM, through puncture of the coccygeal artery or vein into tubes without anticoagulant. After collection, blood samples were transported to the Clinical Analysis Laboratory (BIOLAB) in Arapoti, Paraná State, being centrifuged at 3000 rpm for 10 minutes, then the serum obtained was aspirated and divided into two samples, stored in $1.5 \mathrm{ml}$ Eppendorfs, identified, and frozen at $-20^{\circ} \mathrm{C}$ until analysis. Serum levels of NEFA and BHB were analyzed at one, five, and ten DIM and total calcium at one, two, and five DIM. The NEFA and BHB concentrations were quantified by colorimetric enzymatic methodology in an automatic biochemical analyzer (Biosystems A15), using commercial reagent kits from Randox $^{\circledR}$ (kit NEFA FA115 and kit Ranbut D-3 Hydroxybutyrate RB 1007). For the analysis of total calcium, the Arzenazo III colorimetric method was used.

Milk production was measured after milking, on electronic scales present in automatic milkers, until 100 DIM. The accumulated milk yields up to 30 and 100 DIM were estimated. The first test-day was carried out between 9-36 DIM, by technicians from the Associação Paranaense de Criadores de Bovinos da Raça Holandesa (APCBRH). Milk fat, protein, lactose, total solids contents, somatic cell count (SCC), and milk urea nitrogen (MUN) values were obtained. The fat:protein ratio (FPR) of the first test-day was estimated. In order to assess reproductive performance, farm employees recorded the dates of the first artificial insemination (Al), the number of Al carried out until conception, and the interval between calving and conception (days open).

Statistical analysis was performed using the MIXED procedure of SAS, version 9.4 (SAS Institute Inc., Cary, NC). The statistical model included the fixed effects of farm ( $A$ and B), parity (primiparous and multiparous), and disease occurrence group (healthy and sick). For the reproductive parameters analyzed, the GLIMMIX procedure of SAS (version 9.4) was used, since the data did not have normal distribution. For interpretation and discussion of the results, effects were declared significant when $\mathrm{P} \leq 0.05$, and trends were declared when $0.05<\mathrm{P} \leq 0.10$. Data are presented as least square means.

\section{Results and Discussion}

From the total of 105 cows, 57 were categorized as healthy, and 48 had single or multiple disease events. Eleven cows had dystocia (10.5\%), 27 cows had retained placenta (25.7\%), 17 cows had metritis (16.2\%), seven cows had displaced abomasum (6.7\%), five cows had mastitis (4.8\%), two cows had pneumonia (1.9\%), two cows had clinical hypocalcemia (1.9\%), and one cow had digital dermatitis (1\%).

Forty-eight out of 105 (45.7\%) of the evaluated postpartum cows had one or more disease events. Ruprechter et al. (2020) observed that $45.8 \%$ of Holstein dairy cows were affected by clinical diseases within postpartum period. In a study conducted by Carvalho et al. (2019), with 5,085 Holstein cows in the US, $30.2 \%$ had at least one disease event up to 21 DIM. These early-diagnosed animals represented $65.7 \%$ of cows up to 305 
DIM who were diagnosed as ill, with half of the clinical disease diagnoses occurring up to 15 DIM.

Retained placenta (25.7\%) and metritis (16.2\%) were the disorders with the highest incidences in our study. Melendez et al. (2009) monitored two Chilean herds of Holstein cows and found a lower incidence of retained placenta (15.6\%) compared to our study. Ospina et al. (2010a) observed an incidence of $3.1 \%$ of displaced abomasum, which is lower than the incidence found (6.7\%) in the present study. However, the epidemiological data are peculiar to each herd and their importance consists of what Leblanc, Lissemore, Kelton, Duffield and Leslie (2006) considered a major advance in dairy veterinary medicine in recent decades; the shift to focus on disease prevention and health management, rather than only treatment of a sick individual and emergencies. Therefore, herd diagnosis is essential.

Regarding the occurrence of subclinical diseases, 14 cows had BHB between $1.2 \mathrm{mmol}$ $\mathrm{L}^{-1}$ and $2.9 \mathrm{mmol} \mathrm{L}^{-1}$ at one, five and/or ten DIM, characterizing a $13.33 \%$ incidence of subclinical ketosis according to thresholds already reported (McArt, Nydam, \& Oetzel, 2012). The peak incidence of subclinical ketosis occurs in the first week of lactation and McArt et al. (2012) showed a peak incidence at five DIM, where $22.3 \%$ of the cows evaluated had a first BHB test equal to or greater than 1.2 mmol L-1, which is consistent with our results. Twenty-five cows had a serum calcium level lower than $2.125 \mathrm{mmol} \mathrm{L}^{-1}$ (Goff, 2008) at one and/or two DIM, with an incidence of subclinical hypocalcemia in $23.8 \%$ of experimental cows. Comparatively, other studies found a higher prevalence of subclinical hypocalcemia. Martinez et al. (2016), for example, found a
$44.6 \%$ prevalence of hypocalcemia at one DIM, and Reinhardt, Lippolis, McCluskev, Goff and Horst (2011) found a prevalence of approximately $50 \%$ in multiparous cows, evaluated up to 48 hours after calving, considering cows with hypocalcemia as those with a total calcium lower than $2 \mathrm{mmol} \mathrm{L}^{-1}$. The lower blood calcium levels in the periparturient cow predisposes to the development of other disorders, such as ketosis, retained placenta, displaced abomasum, and mastitis (Goff \& Horst, 1993).

Regarding blood metabolite analysis (Table 2), all evaluated groups (primiparous vs. multiparous, herd $A$ vs. herd $B$, and healthy vs. sick cows) peaked on day 1 for NEFA. The averages were higher than the suggested threshold of $0.57 \mathrm{mmol} \mathrm{L}^{-1}$ (Ospina et al., 2010a); above which a greater risk of developing displaced abomasum, clinical ketosis, metritis, or retained placenta up to 30 DIM was verified in the US. However, high-producing cows have a moderate degree of lipomobilization at the beginning of lactation to support dairy milk production (Chapinal et al., 2012a). In our study, multiparous cows on the day of calving had a higher body condition score (BCS) (3.5) (data not shown) than primiparous (3.3) and had a higher milk yield. Therefore, they probably showed higher NEFA and BHB concentrations because of their higher metabolic energy demands.

In our study, there were no differences in NEFA levels between healthy and sick cows. The NEFA peaked at one DIM and was higher than the threshold suggested by Ospina et al. (2010b) of $0.7 \mathrm{mmol} \mathrm{L}^{-1}$. The serum NEFA increases in the prepartum period and peaks on calving, or the day after, reducing concentration on subsequent days (Leblanc, Leslie, \& Duffield, 2005). The mobilization of 
fatty acids occurs in the postpartum of dairy cows due to the difference between the energy consumed and the energy required for maintenance, lactation, and growth (Grummer,
2008). In the present study, clinical disease occurrences did not influence NEFA at one DIM, probably because they were cows of similar productive challenge.

\section{Table 2}

Serum levels of non-esterified fatty acids (NEFA), $\beta$-hydroxybutyrate (BHB), and total calcium of dairy cows in the postpartum period, according to parity, herd, and clinical events at 1, 2, 5, and 10 days in milk (DIM)

\begin{tabular}{|c|c|c|c|c|c|c|c|c|c|}
\hline \multirow{2}{*}{$\mathrm{DIM}^{1}$} & \multicolumn{2}{|c|}{ Parity $^{2}$} & \multicolumn{2}{|c|}{ Herd } & \multicolumn{2}{|c|}{ Clinical disease $^{3}$} & \multicolumn{3}{|c|}{ P-value } \\
\hline & $\mathrm{P}$ & $\mathrm{M}$ & A & B & Healthy & Sick & Parity & Herd & Clinical disease \\
\hline \multicolumn{10}{|c|}{ Non-esterified fatty acids (mmol L-1) } \\
\hline 1 & 0.59 & 0.92 & 0.61 & 0.90 & 0.78 & 0.73 & 0.01 & 0.04 & 0.71 \\
\hline 5 & 0.57 & 0.74 & 0.59 & 0.71 & 0.65 & 0.66 & 0.11 & 0.32 & 0.89 \\
\hline 10 & 0.48 & 0.59 & 0.53 & 0.54 & 0.52 & 0.55 & 0.21 & 0.90 & 0.69 \\
\hline \multicolumn{10}{|c|}{$\beta$-hydroxybutyrate $\left(\mathrm{mmol} \mathrm{L}^{-1}\right)$} \\
\hline 1 & 0.46 & 0.61 & 0.58 & 0.49 & 0.47 & 0.59 & 0.07 & 0.27 & 0.11 \\
\hline 5 & 0.55 & 0.79 & 0.81 & 0.53 & 0.57 & 0.78 & 0.05 & 0.03 & 0.06 \\
\hline 10 & 0.47 & 0.55 & 0.58 & 0.43 & 0.50 & 0.51 & 0.41 & 0.12 & 0.84 \\
\hline \multicolumn{10}{|c|}{ Total calcium $\left(\mathrm{mmol} \mathrm{L}^{-1}\right)$} \\
\hline 1 & 2.65 & 2.54 & 2.60 & 2.59 & 2.61 & 2.58 & 0.54 & 0.95 & 0.85 \\
\hline 2 & 2.73 & 2.51 & 2.63 & 2.61 & 2.72 & 2.52 & 0.16 & 0.92 & 0.18 \\
\hline 5 & 2.72 & 2.74 & 2.70 & 2.77 & 2.88 & 2.59 & 0.91 & 0.64 & 0.03 \\
\hline
\end{tabular}

The NEFA increase in the first days of lactation overloads the liver, but the liver still has the capacity to re-esterify these fatty acids into triglycerides. However, in the first week after calving, liver overload activates the partial oxidation of fattyacids, leading to ketone bodies (BHB, acetone, and acetoacetate). Cows with a high $\mathrm{BHB}$ in the first week after calving have poor adaptation to a negative energy balance and immunosuppression (McArt et al., 2012), and ketone bodies have direct effects on neutrophil activity, increasing the risk of infectious diseases in the postpartum period
(Suthar, Canelas-Raposo, Deniz, \& Heuwieser, 2013), which was verified in the present study, where sick cows had higher BHB at five DIM.

RegardingNEFAlevelsinthepostpartum period, Ospina et al. (2010b) estimated that milk losses when NEFA concentrations were higher than $0.7 \mathrm{mmol} \mathrm{L}^{-1}$. In this study, highNEFA multiparous cows produced $647 \mathrm{~kg}$ less milk yield in $305 \mathrm{~d}$ and had a 16\% lower chance of pregnancy after the $70 \mathrm{~d}$ voluntary waiting period. Chapinal et al. (2012b) estimated milk losses due to high NEFA postpartum in the first test-day $\left(-1.8 \mathrm{~kg} \mathrm{~d}^{-1}\right)$. 
Concerning $\mathrm{BHB}$, the highest concentrations were registered on day 5 (Table 2), as also detected by McArt et al. (2012). Ospina et al. (2010a) found associations between $\mathrm{BHB}$ levels above $1.0 \mathrm{mmol} \mathrm{L}^{-1}$ with clinical diseases (displaced abomasum, ketosis, metritis, and retained placenta). Above this threshold, cows in the postpartum period were 3.5 times more likely to be diagnosed with displaced abomasum and 2.8 times more likely to have clinical ketosis. Our studies corroborate these data, as cows that presented some disease showed higher $(P=$ $0.06)$ BHB concentrations $\left(0.78 \mathrm{mmol} \mathrm{L}^{-1}\right)$ than healthy cows ( $\left.0.57 \mathrm{mmol} \mathrm{L}^{-1}\right)$ at day 5 . In a study by Giuliodori et al. (2013), cows that developed metritis also had a higher concentration of BHB immediately after calving compared to healthy cows. In our study, the levels of this metabolite were also influenced by the herd effect. Cows in herd A had higher levels of NEFA. This may have occurred due to a greater loss of BCS in the postpartum compared to herd $B(0.5$ vs. 0.4), and they also had a higher BCS at parturition (3.6 vs. 3.4).

Regarding total calcium, blood concentrations were surprisingly high, and consequently the subclinical hypocalcemia incidence was very low, which opposes classical references (Reinhardt et al., 2011). Another unusual result was the absence of a significant difference for $\mathrm{Ca}$ concentrations between primiparous and multiparous cows but, as expected, Ca concentrations increased with time from one to five DIM. Martinez et al. (2016) observed lower total calcium concentrations in multiparous cows on the day after calving. This may be due to lower $\mathrm{Ca}$ absorption in the intestine and greater colostrum yields, with consequently higher calcium sequestration by colostrum. In fact, there were more cows categorized as subclinical hypocalcemic $(\mathrm{Ca}<2.0 \mathrm{mmol}$ $\mathrm{L}^{-1}$ ) with the advance of lactation order, in a study by Reinhardt et al. (2011). In addition, sick cows had lower total calcium levels at five DIM. According to Chapinal et al. (2012a), in periparturient cows this mineral is dependent on dry matter intake, and sick cows typically have lower intake.

Table 3 shows the productive performance of the experimental animals. Sick cows in the postpartum period produced lower daily milk yields ( $\mathrm{P}<0.01$ ) up to $30 \mathrm{DIM}$ (29.8 vs. $33.5 \mathrm{~kg} \mathrm{~d}^{-1}$ ) and lower accumulated yields ( $P$ < 0.01) up to 30 DIM (895 vs. 1006 $\mathrm{kg}$ ). This response was probably diluted until 100 DIM, because there was only a tendency ( $P=0.09$ ) of lower daily and accumulated milk yields for cows with clinical occurrences. Sick cows also showed a trend to have a lower $(\mathrm{P}=$ 0.08) milk total solids content on the first testday than healthy cows; 12.04 and $12.60 \%$, respectively. Furthermore, the milk lactose content was higher $(P<0.01)$ in primiparous, and they also had a lower $(P=0.04)$ SCC compared to multiparous cows.

The response in milk yield between healthy and sick animals was also observed in other studies. Cows without clinical diseases within the first three weeks of lactation had earlier lactation peaks, and produced more milk at peak, compared to cows that had one or more disease events in the postpartum period (metritis, mastitis, lameness, digestive and respiratory problems) (Carvalho et al., 2019). In addition, daily milk yield was impacted by the incidence of clinical diseases within 21 DIM (38.4 kg d-1 on healthy cows vs. $35.4 \mathrm{~kg}$ $\mathrm{d}^{-1}$ on sick ones). Additionally, during 305 DIM, sick cows produced $410 \mathrm{~kg}$ less milk, $17 \mathrm{~kg}$ less milk fat, and $12 \mathrm{~kg}$ less milk protein than healthy cows (Carvalho et al., 2019). 
In a study by Dubuc et al. (2011), retained placenta was associated with a 2.6 $\mathrm{kg}$ decrease in daily milk yield of multiparous cows, corresponding to $753 \mathrm{~kg}$ less milk within 305 DIM. The same authors observed that puerperal metritis decreased milk yield by 259 kg within 305 DIM, and decreased milk yield by $3.7 \mathrm{~kg}$ at the first test-day. Wittrock et al. (2011) also verified the effect of metritis on productive performance; multiparous cows with metritis produced less milk (35.1 vs. 39.2 $\mathrm{kg} \mathrm{d}^{-1}$ ) compared to healthy ones, and they also had lower dry matter (DM) intakes in the first three weeks after calving.

\section{Table 3}

Productive performance of dairy cows in the postpartum period, according to parity, herd, and clinical occurrences

\begin{tabular}{|c|c|c|c|c|c|c|c|c|c|}
\hline \multirow{2}{*}{ Items } & \multicolumn{2}{|c|}{ Parity ${ }^{1}$} & \multicolumn{2}{|c|}{ Herd } & \multicolumn{2}{|c|}{ Clinical disease ${ }^{2}$} & \multicolumn{3}{|c|}{ P-value } \\
\hline & $P$ & $M$ & A & $B$ & Healthy & Sick & Parity & Herd & Clinical disease \\
\hline \multicolumn{10}{|c|}{ Milk, 30 DIM } \\
\hline $\mathrm{kg} \mathrm{d}^{-1}$ & 27.5 & 35.8 & 32.7 & 30.6 & 33.5 & 29.8 & $<0.01$ & 0.15 & $<0.01$ \\
\hline Total & 828 & 1074 & 983 & 918 & 1006 & 895 & $<0.01$ & 0.15 & $<0.01$ \\
\hline \multicolumn{10}{|c|}{ Milk, 100 DIM } \\
\hline $\mathrm{kg} \mathrm{d}^{-1}$ & 34.1 & 41.6 & 38.6 & 37.2 & 39.0 & 36.8 & $<0.01$ & 0.36 & 0.09 \\
\hline Total & 3409 & 4156 & 3850 & 3715 & 3893 & 3672 & $<0.01$ & 0.37 & 0.09 \\
\hline \multicolumn{10}{|c|}{ Milk solids ${ }^{3}$} \\
\hline TS, $\%^{4}$ & 12.49 & 12.15 & 12.41 & 12.24 & 12.60 & 12.04 & 0.32 & 0.61 & 0.08 \\
\hline Fat, $\%^{4}$ & 3.73 & 3.59 & 3.83 & 3.49 & 3.90 & 3.42 & 0.69 & 0.32 & 0.13 \\
\hline Prot, $\%{ }^{4}$ & 3.16 & 3.30 & 3.08 & 3.37 & 3.18 & 3.27 & 0.14 & $<0.01$ & 0.29 \\
\hline Lac, $\%{ }^{4}$ & 4.62 & 4.40 & 4.56 & 4.46 & 4.56 & 4.46 & $<0.01$ & 0.2 & 0.15 \\
\hline $\mathrm{MUN}^{5}$ & 15.2 & 15.4 & 14.6 & 16.1 & 15.7 & 15.0 & 0.79 & 0.06 & 0.34 \\
\hline $\mathrm{SCC}^{6}$ & 97 & 598 & 373 & 322 & 262 & 432 & 0.04 & 0.83 & 0.45 \\
\hline $\mathrm{FPR}^{7}$ & 1.19 & 1.13 & 1.25 & 1.06 & 1.23 & 1.08 & 0.58 & 0.08 & 0.17 \\
\hline
\end{tabular}

${ }^{1}$ Classification based on P: primiparous $(n=32)$ and M: multiparous ( $\left.n=73\right)$.

${ }^{2}$ In the classification of sick animals, those with clinical hypocalcemia, pneumonia, mastitis, metritis, dystocia, digital dermatitis, retained placenta, and/or displaced abomasum were considered: healthy cows $(n=57)$ and sick cows $(n=48)$.

${ }^{3}$ Milk composition data based on the first test-day after calving.

${ }^{4}$ Total solids (TS), fat, protein (Prot), and lactose (Lac).

${ }^{5}$ Milk urea nitrogen, $\mathrm{mg} \mathrm{dL}^{-1}$.

${ }^{6}$ Somatic cell count (SCC $\times 1,000$ cells $\mathrm{mL}^{-1}$ ).

${ }^{7}$ Fat:protein ratio.

Metritis has a negative effect on milk production until the peak of lactation, and dystocia, retained placenta, and stillbirth increase the risk of metritis (Giuliodori et al.,
2013). The lower milk yield observed in cows with metritis may be due to the reduction in DM intake, decreasing the energy available for milk synthesis (Wittrock et al., 2011). This was 
confirmed in a study by Pérez-Báez et al. (2019), where cows with calving disorders (dystocia, twins, or stillbirth) or metritis reduced their DM intake (as a \% of body weight) and produced less energy-corrected milk in the postpartum period. According to the authors, calving disorders or metritis are associated with longterm changes in the partition of nutrients, and changes in the metabolism persist after disease occurrence.

Regarding the reproductive performance of cows (Table 4), there was no effect of clinical occurrences, probably because the population sample was too small to detect changes in reproductive parameters compared to other large studies. There was a herdeffectforallthreereproductiveparameters analyzed, showing that unmonitored factors within the herds determined the reproductive status, as reproduction is multifactorial. Probably the different reproductive protocols and strategies adopted in both herds interfered in the reproductive success, overlapping the factor of clinical disease occurrence. For herd $\mathrm{B}$, the first $\mathrm{Al}$ occurred earlier (18 days compared to herd $A$ ), but this advance reflected the need for a greater number of $\mathrm{Al}$ to achieve pregnancy and the cows showed longer days open. Within the same herd, as all cows were subject to the same environmental and management factors, there was a greater chance that the disease factor would influence reproductive performance.

\section{Table 4}

Reproductive performance of dairy cows in the postpartum period, according to parity, herd, and clinical occurrences

\begin{tabular}{ccccccccccc}
\multirow{2}{*}{ Items } & \multicolumn{2}{c}{ Parity $^{2}$} & \multicolumn{2}{c}{ Herd } & \multicolumn{3}{c}{ Clinical disease $^{3}$} & \multicolumn{3}{c}{ P-value } \\
\cline { 2 - 10 } & P & M & A & B & Healthy & Sick & Parity & Herd & Clinical disease \\
\hline First Al ${ }^{1}$, d & 103 & 92 & 107 & 89 & 97 & 99 & 0.06 & $<0.01$ & 0.64 \\
Al number & 1.9 & 1.7 & 1.5 & 2.1 & 1.8 & 1.8 & 0.59 & 0.03 & 0.69 \\
Days open, d & 134 & 126 & 118 & 143 & 129 & 131 & 0.54 & 0.05 & 0.88
\end{tabular}

${ }^{1}$ Artificial insemination.

${ }^{2}$ Classification based on P: primiparous $(n=32)$ and M: multiparous ( $n=73$ ).

${ }^{3}$ In the classification of sick animals, those with clinical hypocalcemia, pneumonia, mastitis, metritis, dystocia, digital dermatitis, retained placenta, and/or displaced abomasum were considered: healthy cows $(n=57)$ and sick cows $(n=48)$.

The probability of being diagnosed as pregnant in other studies was affected by health status. Metritic cows were less likely to become pregnant at 100 DIM (Giuliodori et al., 2013). Cows with a retained placenta or metritis were less likely to be pregnant at the first service, at 120 DIM, and at 300 DIM (Dubuc et al., 2011). A higher percentage of healthy cows were pregnant compared to sick cows
(75\% vs. 54\%), and the conception rate was higher in healthy than sick cows (Ruprechter et al., 2020). Finally, in a study by Carvalho et al. (2019), pregnancy rate was lower in cows that had clinical diseases, which extended the interval from calving to pregnancy. The same authors concluded that cows that had clinical disease showed reduced pregnancy per Al in breedings performed before 150 and 200 DIM, 
and greater pregnancy losses in all breedings through 305 DIM.

\section{Conclusions}

Approximately $45 \%$ of the experimental cows had one or more clinical occurrences, suggesting that the transition period is in fact a critical phase for dairy cows. Sick cows showed higher BHB concentrations at five DIM than healthy cows. In addition, postpartum non-healthy cows produced significantly less daily and accumulated milk yields in early lactation.

\section{Acknowledgments}

The authors thank the Cooperative Capal in Arapoti, and the owners of the two farms where the collections were performed.

\section{References}

Carvalho, M. R., Penagaricano, F., Santos, J. E. P., DeVries, T. J., McBride, B. W., \& Ribeiro, E. S. (2019). Long-term effects of postpartum clinical disease on milk production, reproduction, and culling of dairy cows. Journal of Dairy Science, 102(12), 11701-11717. doi: 10.3168/jds. 2019-17025

Chapinal, N., Carson, M. E., LeBlanc, S. J., Leslie, K. E., Godden, S., Capel, M., \& Santos, J. E. P. (2012a). The association of serum metabolites in the transition period with milk production and early-lactation reproductive performance. Journal of Dairy Science, 95(3), 1301-1309. doi: 10. 3168/jds.2011-4724
Chapinal, N., Leblanc, S. J., Carson, M. E., Leslie, K. E., Godden, S., Capel, M.,... Duffield, T. F. (2012b). Herd-level association of serum metabolites in the transition period with disease, milk production, and early lactation reproductive performance. Journal of Dairy Science, 95(10), 56765682. doi: 10.3168/ jds.2011-5132

De Amicis, I., Veronesi, M. C., Robbe, D., Gloria, A., \& Carluccio, A. (2018). Prevalence, causes, resolution and consequences of bovine dystocia in Italy. Theriogenology, 107(2), 104-108. doi: 10.1016/j.therio genology.2017.11.001

Dubuc, J., Duffield, T. F., Leslie, K. E., Walton, J. S., \& Leblanc, S. J. (2011). Effects of postpartum uterine diseases on milk production and culling in dairy cows. Journal of Dairy Science, 94(3), 13391346. doi: 10.3168/jds.2010-3758

Giuliodori, M. J., Magnasco, R. P., BecuVillalobos, D., Lacau-Mengido, I. M., Risco, C. A., \& Sota, R. L. (2013). Metritis in dairy cows: Risk factors and reproductive performance. Journal of Dairy Science, 96(6), 3621-3631. doi: 10.3168/jds.20125922

Goff, J. P. (2008). The monitoring, prevention, and treatment of milk fever and subclinical hypocalcemia in dairy cows. Veterinary Journal, 176(1), 50-57. doi: 10.1016/j. tvjl.2007.12.020

Goff, J. P., \& Horst, R. L. (1993). Oral administration of calcium salts for treatment of hypocalcemia in cattle. Journal of Dairy Science, 76(1), 101-108. doi: 10.3168/jds.S0022-0302(93)77328-2

Grummer, R. R. (2008). Nutritional and management strategies for the 
prevention of fatty liver in dairy cattle. The Veterinary Journal, 176(1), 10-20, 2008. doi: 10.1016/j.tvjl.2007.12.033

Leblanc, S. J., Leslie, K. E., \& Duffield, T. F. (2005). Metabolic predictors of displaced abomasum in dairy cattle. Journal of Animal Science, 88(1), 159-170. doi: 10. 3168/jds.S0022-0302(05)72674-6

Leblanc, S. J., Lissemore, K. D., Kelton, D. F., Duffield, T. F., \& Leslie, K. E. (2006). Major advances in disease prevention in dairy cattle. Journal of Dairy Science, 89(4), 1267-1279. doi: 10.3168/jds.S0022-03 02(06)72195-6

Martinez, N., Sinedino, L. D. P., Bisinotto, R. S., Daetz, R., Lopera, C., Risco, C. A.,... Santos, J. E. P. (2016). Effects of oral calcium supplementation on mineral and acid-base status, energy metabolites, and health of postpartum dairy cows. Journal of Dairy Science, 99(10), 8397-8416. doi: 10.3168/jds.2015-10527

McArt, J. A. A., Nydam, D. V., \& Oetzel, G. R. (2012). Epidemiology of subclinical ketosis in early lactation dairy cattle. Journal of Dairy Science, 95(9), 50565066. doi: 10.3168/jds.2012-5443

Melendez, P., Marin, M. P., Robles, J., Rios, C., Duchens, M., \& Archbald, L. (2009). Relationshipbetweenserumnonesterified fatty acids at calving and the incidence of periparturient diseases in Holstein dairy cows. Theriogenology, 72(6), 826-833. doi: 10.1016/j.theriogenology.2009.06.001

Ospina, P. A., Nydam, D. V., Stokol, T., \& Overton, T. R. (2010a). Evaluation of nonesterified fatty acids and $\beta$-hydroxybutyrate in transition dairy cattle in the northeastern United States: critical thresholds for prediction of clinical diseases. Journal of Dairy Science, 93(2), 546-554. doi: 10. 3168/jds.2009-2277

Ospina, P. A., Nydam, D. V., Stokol, T., \& Overton, T. R. (2010b). Associations of elevated nonesterified fatty acids and $\beta$-hydroxybutyrate concentrations with early lactation reproductive performance and milk production in transition dairy cattle in the northeastern United States. Journal of Dairy Science, 93(4), 15961603. doi: 10.3168/jds.2009-2852

Overton, T. R., \& Waldron, M. R. (2004). Nutritional management of transition dairy cows: Strategies to optimize metabolic health. Journal of Dairy Science, 87(Suppl. 1), E105-E119. doi: 10.3168/jds.S00220302(04)70066-1

Pérez-Báez, J., Risco, C. A., Chebel, R. C., Gomes, G. C., Greco, L. F., Tao, S.,... Galvão, K. N. (2019). Association of dry matter intake and energy balance prepartum and postpartum with health disorders postpartum: Part I. Calving disorders and metritis. Journal of Dairy Science, 102(10), 9138-9150. doi: 10.3168/jds.2018-15878

Reinhardt, T. A., Lippolis, J. D., McCluskev, B. J., Goff, J. P., \& Horst, R. L. (2011). Prevalence of subclinical hypocalcemia in dairy herds. Veterinary Journal, 188(1), 122-124. doi: 10.1016/j.tvjl.2010.03.025

Ribeiro, E. S., Gomes, G., Greco, L. F., Cerri, R. L. A., Vieira, A., Neto, Monteiro, P. L. J., Jr.,... Santos, J. E. P. (2016). Carryover effect of postpartum inflammatory diseases on developmental biology and fertility in lactating dairy cows. Journal of Dairy Science, 99(3), 2201-2220. doi: 10.3168/ jds.2015-10337 
Ruprechter, G., Noro, M., Meotti, O., Batista, C., Loures Adrien, M., Barca, J., \& Meikle, A. (2020). Endocrine and reproductive parameters in sick and healthy primiparous and multiparous dairy cows. Theriogenology, 141(1), 173-179. doi: 10. 1016/j.theriogenology.2019.09.026

Sordillo, L. M., \& Raphael, W. (2013). Significance of metabolic stress, lipid mobilization, and inflammation on transition cow disorders. Veterinary Clinics of North America Food Animal Practice, 29(2), 267-278. doi: 10.1016/j.cvfa.2013.03.002

Suthar, V. S., Canelas-Raposo, J., Deniz, A., \& Heuwieser, W. (2013). Prevalence of subclinical ketosis and relationships with postpartum diseases in European dairy cows. Journal of Dairy Science, 96(5), 2925-2938. doi: 10.3168/jds.2012-6035
Venjakob, P. L., Borchardt, S., \& Heuwieser, W. (2017). Hypocalcemia - Cow-level prevalence and preventive strategies in German dairy herds. Journal of Dairy Science, 100(11), 9258-9266. doi: 10.31 68/jds.2016-12494

Wittrock, J. M., Proudfoot, K. L., Weary, D. M., \& Von Keyserlingk, M. A. G. (2011). Short communication: Metritis affects milk production and cull rate of Holstein multiparous and primiparous dairy cows differently. Journal of Dairy Science, 94(5), 2408-2412. doi: 10.3168/jds.2010-3697 
